\title{
KAJIAN HERMENEUTIK SCHLEIERMACHER TERHADAP KUMPULAN LAGU KELOMPOK MUSIK EFEK RUMAH KACA
}

\author{
Putri Octaviani, Sarwit Sarwono, dan Bustanuddin Lubis \\ Program Studi Pendidikan Bahasa Indonesia \\ Jurusan Pendidikan Bahasa dan Seni \\ FKIP Universitas Bengkulu \\ putrioctaviani933@yahoo.co.id
}

\begin{abstract}
Abstrak
Penelitian ini bertujuan untuk menemukan dan memahami makna teks yang terdapat pada lirik lagu Efek Rumah Kaca dengan menggunakan konsep interpretasi gramatis dan interpretasi psikologis Schleiermacher. Metode yang digunakan dalam penelitian ini adalah metode Hermeneutik Schleirmacher. Hasil penelitian ini menunjukan bahwa dalam lirik-lirik kelompok musik Efek Rumah Kaca banyak terdapat repetisi atau pengulangan baik dalam kata, kalimat ataupun bait, kemudian juga terdapat kata dalam lirik yang saling berkaitan atau disebut hubungan kausal. Selain itu, ada pula beberapa kata yang mendapat imbuhan sehingga terjadi gramatikalisasi yaitu perubahan bentuk suatu kata yang memengaruhi makna kata dan makna lirik lagu tersebut. Penelitian ini juga menunjukan bahwa Lirik-lirik yang ditulis tercipta ketika penulis melihat keadaan dan isu-isu sosial yang terjadi di masyarakat pada saat lirik ini diciptakan. Contohnya lirik lagu berjudul Jalang dan Di Udara yang isinya berbicara mengenai seseorang yang memiliki kekuasaan. Lirik yang berjudul Jalang berbicara mengenai ketidakadilan yang terjadi di masyarakat pada saat itu. Ketidakadilan yang terjadi berupa perampasan hak-hak dasar dari seorang manusia yaitu hak berpendapat dan berekspresi. Selain itu, ada pula lirik berjudul Di Udara yang berbicara mengenai seorang aktivis yang dibunuh dalam perjalannya dan sampai saat ini kebenaran kasusnya tidak juga terungkap.
\end{abstract}

Kata kunci: Efek rumah kaca, Hermeneutik, Schleiermacher

\begin{abstract}
This research aims to add point out understand the meaning of the text of Efek Rumah Kaca lyrics, using the concept of Schleiermacher's grammatical interpretation and psychological interpretation. The method used in this research is the Schleiermacher's Hermeneutics method. The results of this research as follows. In the form of grammatical interpretation that shows that in the lyrics of the Efek Rumah Kaca music group there are many repetitions either in words, sentences or stanzas, then there are also words in interrelated lyrics or causal relationships. In addition, there are also some words that get affixes so that there is grammaticalisation, namely changing the shape of a word that affects the meaning of the word and the meaning of the lyrics. This research also shows that the written lyrics are produced when the writer influences phenomenon of the social conditions and issues that occur in the community when the lyrics are produced. Examples such as lyrics entitled Jalang and Di Udara whose contents speak of someone who has rule. The lyrics entitled Jalang spoke about the injustices that occurred in the community at that time. Injustice that occurs in the form of deprivation of basic rights of a human being is the right to conclude and
\end{abstract}


express. In addition, there are also lyrics titled Di Udara that talk about an activist who was killed on his journey and until now the truth of the case is not revealed.

Keywords: Efek Rumah Kaca, Hermeneutics, Schleiermacher's

\section{PENDAHULUAN}

Efek Rumah Kaca adalah grup musik indie yang berasal dari Jakarta yang terdiri dari Cholil Mahmud (vokal utama, gitar), Adrian Yunan Faisal (vokal, bass, gitar), Poppie Airil (vokal latar, bass) dan Akbar Bagus Sudibyo (drum, vokal latar). Mereka dikenal oleh para pecinta musik di Indonesia dengan lagu-lagu mereka yang liriknya ditulis dan diciptakan sendiri oleh vokal utamanya dan beberapa lagunya dibantu oleh teman-teman satu grup musiknya.

Mereka juga mulai dikenal luas oleh para pencinta musik di Indonesia karena lirik lagu mereka yang menyentuh dan memotret keadaan sosial masyarakat di sekitar mereka. Sebagai teks lirik lagu mereka tidak lahir dari lamunan kosong, sejalan dengan yang dikatakan (Hadi, 2016:77) bahwa teks tidak lahir dari lamunan kosong dan yang disebut realitas bukan hanya realitas sosial politik, serta peristiwa-peristiwa dalam kehidupan yang dapat dialami secara empiris. Sejak merilis debut album Self Titled pada September 2007 Efek Rumah Kaca mendapat respon positif dari berbagai media dan kalangan.

Contohnya lirik lagu dari Efek Rumah Kaca yang berjudul "Jalang" yang liriknya bercerita mengenai fenomena sosial di masyarakat, di mana dapat dilihat dari potongan liriknya berbunyi "siapa yang berani bernyanyi nanti akan dikebiri, siapa yang berani menari nanti akan dieksekusi." Lirik yang diciptakannya ini seakan menyinggung kehidupan nyata pada masa lampau di mana pada saat itu kita tidak memiliki hak kebebasan untuk berbicara dan melakukan hal-hal yang kita inginkan, jika kita menentang salah-salah kita bisa masuk penjara.
Lirik lagu yang ditulis oleh band Efek Rumah Kaca ini banyak mengandung makna tersirat sehingga untuk memahami teks lirik lagu band Efek Rumah Kaca diperlukan prinsip-prinsip sebagaimana yang ditawarkan oleh teori hermeneutik sebab, teori hermeneutik ini adalah seni memahami, terutama memahami sebuah teks. Hermeneutika adalah kata yang sering didengar dalam bidang teologi, filsafat, bahkan sastra walaupun dalam sastra teori hermeneuitik masih jarang digunakan. Tetapi akhir-akhir ini teori hermeneutika semakin digandrungi oleh para peneliti akademis, kritikus sastra, sosiolog, sejarawan, antropolog, filosof, maupun teolog, khususnya untuk mengkaji, memahami, dan menafsirkan teks.

Hermeneutik selalu berpusat pada fungsi penafsiran teks. Dalam buku (Lubis, 2015:181) secara etimologi, hermeneutik berasal dari kata 'hermeneuin' yang berarti menafsirkan atau seni memberikan makna (the art of interpretation). Maka dari itu hermeneutik kerap kali diartikan sebagai teori yang mengkaji tentang makna, meski terjadi perubahan atau modifikasi terhadap teori-teori hermeneutik, tetap saja hermeneutik berintikan seni memahami teks.

Dalam bukunya (Hardiman, 2015:41) Schleiermacher berpendapat bahwa tujuan pemahaman adalah menghadirkan kembali dunia mental penulisnya atau saya memakai istilah dari Palmer "rekonstruksi pengalaman mental pengarang teks". Ditekankan bahwa targetnya bukan emosi, melainkan pikiran si penulis, pencipta ataupun pengarang tersebut. Jadi pemikiran Schleiermacher tentang hermeneutik itu, yaitu pemahaman sebagai 
sebuah seni adalah mengalami kembali proses mental dari pengarang teks.

Adapun penelitian sejenis yang penulis temui adalah di sebuah tesis yang diteliti oleh Sari Wahyuni (2017) dengan judul Analisis Novel 99 Cahaya Di Atas Langit Eropa Karya Hanum Salsabiela Dan Rangga Almahendra Dengan Menggunakan Teori Hermeneutik Wilhelm Dilthey. Penelitian ini memiliki kesamaan dengan penelitian yang dilakukan penulis yaitu sama-sama menggunakan teori hermeneutik tetapi dengan objek yang berbeda dan teori hermeneutik dari dua tokoh yang berbeda pula.

Ada juga jurnal ilmah yang mengkaji mengenai lirik lagu dari band Efek Rumah Kaca yaitu jurnal ilmiah dengan Judul Semiotika Lagu Hijau Di Album Sinestesia Efek Rumah Kaca, yang ditulis oleh Rd. Giat Raharja Kusuma, Sri dewi Setiawati, dan Baruna Tyaswara (2015) penelitian ini memiliki kesamaan dengan apa yang sedang penulis kaji yaitu mengkaji lirik lagu dari band Efek Rumah Kaca tetapi menggunakan teori analisis yang berbeda.

Karena belum banyaknya penelitian mengenai teori hermeneutik ini dalam bidang sastra, membuat penulis tertarik untuk mengkaji lirik lagu dari kelompok musik Efek Rumah Kaca ini menggunakan teori hermeneutik karena teori ini bisa mengkaji sebuah tulisan apa saja yang mengandung makna. Penulis tertarik untuk mengkaji lirik lagu dari kelompok musik Efek Rumah Kaca ini karena lirik-lirik yang ditulisnya kebanyakan mengangkat isu-isu keadaan sosial masyarakat di sekitar mereka.

Alasan penulis memilih album self titled ini untuk dianalisis karena Album ini merupakan album pertama yang membuat nama dari kelompok musik Efek Rumah Kaca menjadi basar dan dikenal oleh masyarakat. Lirik-lirik yang terdapat di dalam album ini juga sangat kuat sehingga dibutuhkan teori hermeneutik untuk mengkajinya. Album pertama dari kelompok musik Efek Rumah Kaca ini terbilang sukses karena mereka dapat menjadi nominasi diberbagai penghargaan musik hingga dapat memenangkan penghargaan tersebut, seperti penghargaan Rolling Stone Indonesia dengan kategori rookie of the year dan Class Music Heroes 2009 dengan kategori Class Music Heroes.

Penelitian ini juga dapat bermanfaat untuk bidang Pendidikan contohnya ketika mata pelajaran puisi, Lagu ini juga dapat diperdengarkan untuk memancing imajinasi siswa dan memancing pemahaman siswa. Oleh sebab itu, penulis tertarik ingin meneliti lirik lagu Efek Rumah Kaca ini menggunakan teori hermeneutik Schleiermacher sehingga tidak terjadi kesalahpemahaman terhadap lirik lagu ini dan membuat lirik lagu ini akan lebih mudah dipahami para pembacanya.

\section{METODE}

Metode yang digunakan dalam penelitian ini adalah metode kualitatif, menggunakan pendekatan Hermeneutik sastra, adapun teori khusus yang digunakan yaitu teori Hermeneutik Schleiermacher. Teknik analisis data dalam penelitian ini meliputi: (1) membaca dan memahami liriklirik dari band Efek Rumah Kaca, (2) mendeskripsikan dan memaknai lirik-lirik dari band Efek Rumah Kaca menggunakan konsep interpretasi gramatis seperti berikut,

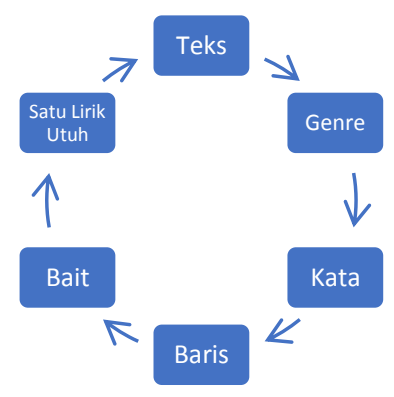

(3) mendeskripsikan dan memaknai liriklirik dari band Efek Rumah Kaca menggunakan konsep interpretasi psikologis seperti berikut. 


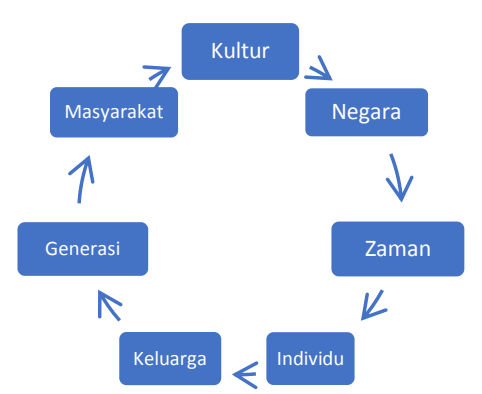

(4) mendeskripsikan dan memaknai liriklirik dari band Efek Rumah Kaca dengan menggabungkan konsep interpretasi gramatis dan interpretasi psikologis secara integral, (5) menarik kesimpulan terhadap interpretasi makna pada lirik lagu Efek Rumah Kaca.

\section{HASIL PENELITIAN DAN PEMBAHASAN}

A. Deskripsi umum lirik lagu Efek Rumah Kaca

Secara umum lirik-lirik lagu Efek Rumah Kaca ini berbicara mengenai fenomena sosial hingga kritik-kritik sosial terhadap berbagai kalangan, mulai dari kritikan untuk masyarakat maupun pemerintahan yang ada di Indonesia, sampai dengan lagu yang bertemakan religius tetapi tetap dikemas dengan sangat menarik dan tetap dengan melihat fenomena sosial yang terjadi.

Awal tahun 2000-an lirik-lirik romantisme sangat digemari. Lirik-lirik lagu dengan kata cinta menjadi tema semua lagu yang ada di Indonesia, bukan hanya lagu tetapi puisi, pantun dan film pun banyak dihiasi dengan tema percintaan atau romantisme. Berbeda dengan Lirik-lirik yang ditulis oleh efek Rumah Kaca, liriknya malah berlaku sebaliknya, lirik yang diciptakannya berawal dari fenomena sosial yang terjadi pada saat itu, perasaan peduli atas sebuah situasi tertentu dan kebanyakan menentang keadaan yang terjadi, lirik-lirik bernada protes atau dapat disebut lirik perlawanan. Lirik perlawanan ini biasanya pasti menimbulkan pro dan kontra sehingga cenderung mendapatkan tempat di masyarakat karena masyarakat tersebut memang menyukai ataupun hanya karena rasa penasaran yang membuat lirik seperti ini akhirnya dicari oleh masyarakat.

Lirik yang dibuat oleh kelompok musik Efek Rumah Kaca ini ditulis seakan penulis ingin membagikan keresahan yang ia rasakan didalam dirinya sehingga masyarakat yang mendengarkan musiknya ataupun membaca liriknya akan ikut merasakan apa yang penulis rasakan ketika menciptakan lirik-lirik lagu pada album pertamanya ini. Di dalam penelitian ini lirik lagu mempunyai kesamaan dengan puisi maka teks lirik yang ada pada penelitian ini termasuk ke dalam genre teks sastra yaitu sastra jenis puisi. Definisi mengenai teks-teks puisi tidak hanya mencakup jenis-jenis sastra, melainkan pula ungkapan Bahasa yang bersifat pepatah, pesan iklan, semboyan politik, syair lagu-lagu pop, dan doa-doa (luxemburg, 1992:175).

B. Interpretasi Gramatis

Dalam interpretasi gramatis penulis akan mencermati dan memaknai kata dalam baris-baris kemudian menemukan makna dalam bait, dan makna secara utuh. Jika kita mencermati lirik dari kelompok musik ini kita akan menemukan banyak terjadinya repetisi atau pengulangan baik dalam kata, kalimat ataupun bait, selain itu ada pula beberapa kata yang mendapat imbuhan sehingga terjadi gramatikalisasi yaitu perubahan bentuk suatu kata yang juga mempengaruhi makna kata tersebut, kemudian juga terdapat kata dalam lirik yang saling berkaitan. Seperti pada lirik lagu yang berjudul Jalang, terdapat kata-kata saling berkaitan. 


\begin{tabular}{|c|c|c|}
\hline \multicolumn{3}{|c|}{ Hubungan Kausal } \\
\hline [bernyanyi] & 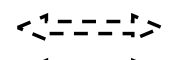 & [dikebiri] \\
\hline [menari] & 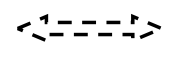 & [dieksekusi] \\
\hline [siapa] & 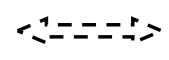 & [di] \\
\hline [mereka] & 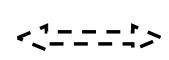 & [kami] \\
\hline [suci] & 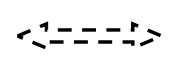 & [jalang] \\
\hline [penguasa] & 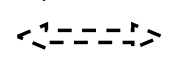 & [tak berkuasa] \\
\hline
\end{tabular}

Kata-kata di atas memiliki hubungan kausal antara kata satu dengan kata lainnya dalam teks lirik tersebut. Kata bernyanyi di dalam lirik lagu Jalang ini berkaitan dengan kata dikebiri sedangkan kata menari berkaitan dengan kata dieksekusi kata dikebiri dan dieksekusi ini juga merupakan sebuah kata pasif berarti ketika ada seseorang yang dikebiri dan dieksekusi berarti ada orang yang mengebiri dan mengeksekusinya.

Siapa yang berani di sini tidak dibicarakan secara jelas siapa tetapi kata siapa ini dikaitkan dengan kata di dan lirik ini juga membedakan antara mereka dan kami kemudian suci dan jalang jelas sekali menerangkan bahwa orang yang mengebiri di sini mendapat sebutan orang yang suci sedangkan orang yang berani bernyanyi dan menari disebutnya dengan jalang, jalang memiliki arti liar atau nakal atau sebuah perbuatan yang melanggar asusila. maka ketika kita melihatnya secara utuh lirik lagu ini bisa saja ditujukan untuk seorang penguasa yang bisa mengebiri dan mengeksekusi seseorang dan yang menjadi korbannya adalah orang yang tak berkuasa. Di sini terlihat bagaimana kata yang satu dengan kata yang lain tersebut memiliki hubungan kausal.

Jika diartikan secara utuh lirik ini bercerita mengenai seseorang yang mempunyai kekuasaan sehingga ia menyalahgunakan kekuasaan yang ia miliki dengan seenaknya dan membuat orang lain yang tidak sejalan dengan apa yang ia inginkan dapat disingkirkannya dengan mudah tanpa jejak lalu membuat orang-orang ketakutan dan tidak berani melawan yang menyebabkan orang-orang yang lebih kecil tidak berani bersuara dan berkreasi sesuka hatinya. Menari di sini dapat berarti berekspresi dengan menunjukan sesuatu. Sedangkan eksekusi berarti pelaksanaan keputusan hakim untuk seseorang yang melakukan pelanggaran pidana khususnya hukuman mati.

Di dalam 12 judul lagu yang ditulisnya ini banyak terjadi pengulangan-pengulangan kata maupun kalimat pada liriknya, seperti pada bait pertama lirik lagu yang berjudul Jalang yang sudah dibicarakan di atas terdapat pengulangan. Pengulangan yang sangat ditekankan pada kata bernyanyi, dikebiri, menari, dan kata dieksekusi. Adapula pengulangan yang terjadi pada lirik lagu yang berjudul Di Udara, yaitu terdapat kalimat "tapi aku tak pernah mati, tak akan berhenti" dan lirik lagunya yang berjudul Efek Rumah Kaca terdapat kalimat "kita akan terbakar" kalimat-kalimat ini mendapat banyak pengulanganan dalam liriknya sehingga kalimat itu mendapat perhatian dan menjadi pusat dari liriknya tersebut. Pengulangan-pengulangan yang ada juga mengartikan bahwa ada makna yang sangat dalam pada kalimat ini, kalimat ini memiliki makna yang sangat penting sehingga diulang hingga berkalikali dalam liriknya.

Kemudian adapula kata pada liriknya ini mendapat imbuhan sehingga membuat kata tersebut menjadi berubah makna seperti lagu yang berjudul Desember yang mendapatkan penambahan imbuhan pada masingmasing kata yaitu "berelegi dan menanti", kata berelegi berasal dari kata dasar elegi yang berarti nyanyian yang mengandung ratapan atau 
kesedihan kemudian mendapat tambahan imbuhan ber- yang berubah makna menjadi adanya sesorang yang sedang dalam keadaan kesedihan lalu pada kata menanti yang berawal dari kata dasar nanti yang berarti waktu kemudian dan mendapat imbuhan mehingga artinya pun berubah menjadi menunggu suatu hal. Adapula lirik lagu yang berjudul Jatuh Cinta Itu Biasa Saja, di dalam liriknya tersebut terdapat sebuah frasa yaitu "kita berdua", frasa ini menuju kepada orang yang sama, yaitu orang yang sedang berdua.

C. Interpretasi Psikologis

Sebelumnya pada deskripsi umum lirik lagu kelompok musik Efek Rumah Kaca ini penulis sudah menyampaikan bahwa lirik-lirik yang ditulisnya ini bercerita mengenai fenomena sosial yang terjadi, kritik sosial terhadap berbagai kalangan hingga religius, untuk itu sekarang kita akan mengulik apa yang melatarbelakangi atau menginspirasi penulis ketika menulis liriknya ini. Lirik-lirik yang dibuat oleh kelompok musik ini seakan mencerminkan keadaan Indonesia pada saat itu seperti lirik lagunya yang berjudul Jalang, Lirik ini menggambarkan perasaan dari penulis karena melihat fenomena sosial yang terjadi pada saat itu.

Ketidakadilan sering sekali terjadi di lingkungannya di mana sering sekali terjadinya perampasan hak-hak dasar dari seorang manusia yaitu hak berpendapat dan berekspresi inilah yang menggerakan penulis tergerak menulis lirik lagu ini. Lagu ini keluar pada tahun 2007 berarti lirik lagu ini dibuat oleh penulis sekitar tahun 90-an sampai 2000-an. Jika kita ingat lagi pada tanggal 21 Juni 1994, beberapa media massa, salah satunya Tempo dicabut surah izin penerbitannya. Hal itu dikarenakan mereka mengeluarkan laporan investigasi tentang berbagai masalah penyelewengan oleh pejabatpejabat Negara. Pembredelan itu diumumkan langsung oleh bapak Harmoko selaku menteri penerangan pada saat itu. Selain Tempo, Tabloid Editor dan Tabloit Detik juga dicabut Surat Izin Usaha Penerbitan Pers (SIUPP). Sekelompok wartawan yang kecewa pada sikap Persatuan Wartawan Indonesia (PWI) yang menyetujui pembredelan Tempo, Editor, dan Detik, kemudian mendirikan Aliansi Jurnalis Independen (Inilahcom, 2014)

Pada saat itu kebebasan berpendapat kita menjadi sangat terbatas. Seseorang yang mengkritik atau mengeluarkan pendapatnya, bisa saja mendapatkan ancaman hukuman dari orang-orang yang memiliki kekuasaan tinggi. Maka dari itu akhirnya banyak orang memilih untuk bungkam daripada harus menanggung hukuman yang akan diterima. Siapa yang berani melawan dan tidak menggubris peringatan sebelumnya nanti akan diputus haknya untuk berbicara, bisa saja hukuman penjara agar ia tidak bisa lagi berpendapat dan berbicara sembarangan kepada orang-orang mengenai kebenaran atau dihukum mati.

Seperti pada contoh kasus pembunuhan wartawan Udin, ia adalah seorang wartawan Surat Kabar Harian (SKH) Bernas terbit di Yogyakarta. Udin 'dihilangkan' karena tulisannya yang mengusik penguasa kala itu. Beberapa tulisan Udin mengkritisi kekuasaan Orde Baru dan militer. Ada pihak-pihak tertentu berupaya mengalihkan kasus kematian Udin ini. Tak hanya itu, sebelum meninggal, banyak juga kejadian yang aneh dan ganjil yang terjadi terkait kematian Udin. Kasus kematian Udin yang disebut-sebut 
menjadi tumbal kepentingan politik dan tentara itu sampai saat ini tidak pernah terkuak. Kasus ini membuktikan bahwa kebebasan untuk berpendapat tidak mendapat perlindungan dari pemerintahan. Lirik lagu ini bisa saja terinspirasi dari kasus-kasus yang terjadi menganai tidak adanya kebebasan berpendapat.

Banyaknya kasus-kasus yang terjadi ini membuat banyak orang sekarang tidak berani mengutarakan pendapatnya dan memilih berbohong untuk melindungi dirinya dari pada ia berbicara kemudian ia akan mendapat hukuman. Jika kita jujur dan berniat membela orang lain kita malah akan terkena imbasnya, kejujuran sudah tidak ada nilainya lagi. Lirik yang digunakan juga sangat menyinggung mengenai penegakan keadilan.

Lirik lagu yang berjudul jalang ini serupa dengan lirik yang berjudul Di Udara yang juga merupakan lirik yang diangkat dari fenomena sosial untuk mengkritik seseorang yang berkuasa. Ketika kita membaca judul dari liriknya ini yaitu Di Udara dan kemudian membaca keseluruhan liriknya kita pasti akan langsung diingatkan pada kisah yang terjadi pada seorang aktivis HAM bernama Munir yang meninggal karena diracun di dalam pesawat saat perjalannya dan sampai saat ini tidak terungkap kebenaran yang sesungguhnya dari kasus kematiannya ini. Album Efek rumah kaca ini sendiri dipasarkan pada tahun 2007 belum lama setelah kejadian yang menimpa seorang aktivis HAM bernama Munir. Kasus yang menyebabkan kematian seorang aktifis HAM ini terjadi pada tahun 2004.

Lirik yang berjudul Jalang dan Di Udara ini juga memiliki kemiripan dengan lirik yang berjudul Jatuh Cinta Itu Biasa Saja yaitu juga merupakan fenomena sosial yang terjadi tetapi lirik yang ditulisnya lebih ditujukan untuk mengkritik pergaulan generasi muda yang sangat bebas sehingga banyak remaja bergaul tanpa batasan dan etika kemudian generasi muda yang mudah terpengaruh lingkungan sehingga membuat banyak remaja salah mengartikan cinta hingga cinta disini diartikan sampai pada tahap yang tidak seharusnya.

Lirik lagunya yang berjudul Cinta Melulu juga masih berbicara mengenai fenomena sosial yang terjadi saat itu tetapi pada lirik Cinta Melulu ini liriknya seperti lebih diperuntukkan kepada pasar musik yang mendukung cinta berlebihan itu dengan menciptakan lagu-lagu yang pertemakan percintaan. Penulis seperti terinspirasi dari kata cinta yang menjadi tema semua lagu yang ada di Indonesia, bukan hanya lagu, puisi, pantun dan film pun banyak dihiasi dengan kisah percintaan, pada tahun 2000-an dan sampai pada tahun album ini dikeluarkan yaitu 2007.

Lirik yang berjudul Debu-debu Beterbangan merupakan lirik yang juga berbicara mengenai fenomena sosial yang terjadi di masyarakat tetapi dengan lirik yang ditulisnya lebih religius sedikit berbeda dengan lirik-lirik lain yang sudah ditulisnya. Ketika membaca lirik ini kita akan teringat pada surat Al'Asr (ayat 1-3) karena terdapatnya frasa Demi Masa yang terletak pada awal liriknya dan dilanjutkan dengan lirik "sungguh kita tersesat". Lirik tersebut memiliki kesamaan dengan arti dari surat Al'Asr yang berbunyi "wal-'așr ( Demi masa), innal-insāna lafī khusr (sungguh, manusia berada dalam kerugian)" (Nugraha, 2014:601). Ketika membaca liriknya kita juga akan teringat pada surat Al Waqiah (Q.S 56, ayat 4-6) karena terdapatnya frasa Debu-debu Beterbangan, yang sama dengan arti 
dari surat Al Waqiah yang berbunyi "Fakaanat habaa-am munbatstsaa (Maka jadilah ia debu yang beterbangan)" (Nugraha, 2014:534).

Lirik ini ditulisnya karena terispirasi dari fenomena sosial yang ada ketika penulis melihat masyarakat yang jauh dari ajaran agama dan lebih memilih mendekati kegiatan-kegiatan yang diharamkan oleh Allah dan juga lirik ini juga terinspirasi dari surat yang ada di dalam Al-Quran yang mengisahkan bagaimana manusia akan menyesali perbuatannya dikemudian hari karena tidak menjalankan perintah Allah untuk menjauhi laranganlarangannya.

Di dalam lirik lagunya ini penulis menggunakan kata manusia untuk menguatkan liriknya seperti lirik yang berbunyi "Demi masa, sungguh kita tersesat, membiaskan yang haram, karena kita manusia" Penulis memilih manusia karena manusia adalah makhluk yang tidak sempurna dan banyak memiliki kekurangan. Manusia adalah makluk yang tidak pernah merasa puas dan lebih suka pada hal-hal yang menyenangkan saja oleh sebab itu, penulis menulis liriknya ini untuk mengingatkan manusia agar terus mengingat mengenai betapa mengerikannya hari akhir atau kiamat itu akan terjadi dan betapa meruginya orang-orang yang tidak beriman dan menyia-nyiakan waktunya.

\section{PENUTUP}

\section{Kesimpulan}

Berdasarkan hasil dan pembahasan yang ada dapat disimpulkan bahwa dalam lirik-lirik kelompok musik Efek Rumah Kaca interpretasi gramatis yang muncul yaitu repetisi atau pengulangan baik dalam kata, kalimat ataupun bait, kemudian juga terdapat kata dalam lirik yang saling berkaitan atau penulis menyebutnya dengan hubungan kausal seperti yang ada pada lirik yang berjudul Jalang, Melankolia dan Belanja Terus Sampai Mati. Ada pula beberapa kata yang mendapat imbuhan sehingga terjadi gramatikalisasi yaitu perubahan bentuk suatu kata yang juga mempengaruhi makna kata tersebut.

Pada tahap interpretasi psikologis terlihat bahwa lirik-lirik yang ditulisnya ini tercipta dari fenomena sosial yang terjadi saat itu, sehingga timbulah lirik yang menyentuh dan sedikit berisi kritik-kritik sosial. Semua lirik yang ditulisnya ini bergerak dari keadaan lingkungan sosial dari penulis sendiri ketika melihat keadaan Indonesia saat itu yang kemudian dituangkannya dalam bentuk tulisan dan akhirnya menjadi sebuah lirik lagu yang menjadi medium untuk menyampaikan perasaan yang dirasakan penulis sehingga dapat sampai kepada banyak orang. Seperti lirik yang berjudul Jalang dan Belanja Terus Sampai Mati yang menceritakan mengenai lingkungan penulis pada saat itu dimana pada tahun lirik lagu ini diciptakan sekitar tahun 2000-an dan sampai pada tahun album ini dikeluarkan yaitu pada tahun 2007 ketidakadilan marak sekali terjadi. Adapula lirik yang berjudul Belanja Terus Sampai Mati, liriknya ini bercerita menganai tingginya tingkat konsumsi masyarakat.

\section{DAFTAR PUSTAKA}

Hadi, Abdul. 2016. Hermeneutika Estetika dan Religiusitas: Esai-Esai Sastra Sufistik dan Seni Rupa. Jakarta: Sadra Press.

Hardiman, F. Budi. 2015. Seni Memahami: Hermeneutik dari Schleiermacher sampai Derrida. Yogyakarta: PT Kanisius.

Inilahcom (2014, 1 Juni). 5 Peristiwa Penting Di Indonesia Pada Era 90-An.(online). Diakses tanggal 19 Agustus 2018, dari https://m.inilah.com/news/detail/210 5105/5-peristiwa-penting-di indonesia-pada-era-90an 
Kusuma, Rd. Giat Raharja; Sri Dewi Setiawati dan Baruma Tyaswara. 2015. "Semiotika Lagu Hijau Di Album Sinestesia Efek Rumah Kaca." Jurnal Fakultas IImu Komunikasi Universitas BSI. Vol. II No. 2 September 2015.

Lubis, Akhtar Yusuf. 2015. Filsafat Ilmu: Klasik Hingga Kontemporer. Jakarta: PT RajaGrafindo Persada.

Luxemburg, Jan Van; Mieke Bal dan Willem G. Weststeijn. 1992. Pengantar IImu Sastra. Jakarta: PT Gramedia.
Nugraha, Eva; Mu'min Maulana dan Abdul Bari. 2014. Al-Quran dan Terjemahannya. Tangerang Banten: Penerbit Sahifa.

Wahyuni, Sari. 2017. “Analisis Novel 99 Cahaya Di Atas Langit Eropa Karya Hanum Salsabiela dan Rangga Almahendra dengan Menggunakan Teori Hermeneutik Wilhelm Dilthey". Thesis Tidak dipublikasikan. Program Pascasarjana (S2) Pendidikan Bahasa Indonesia, Universitas Bengkulu. 